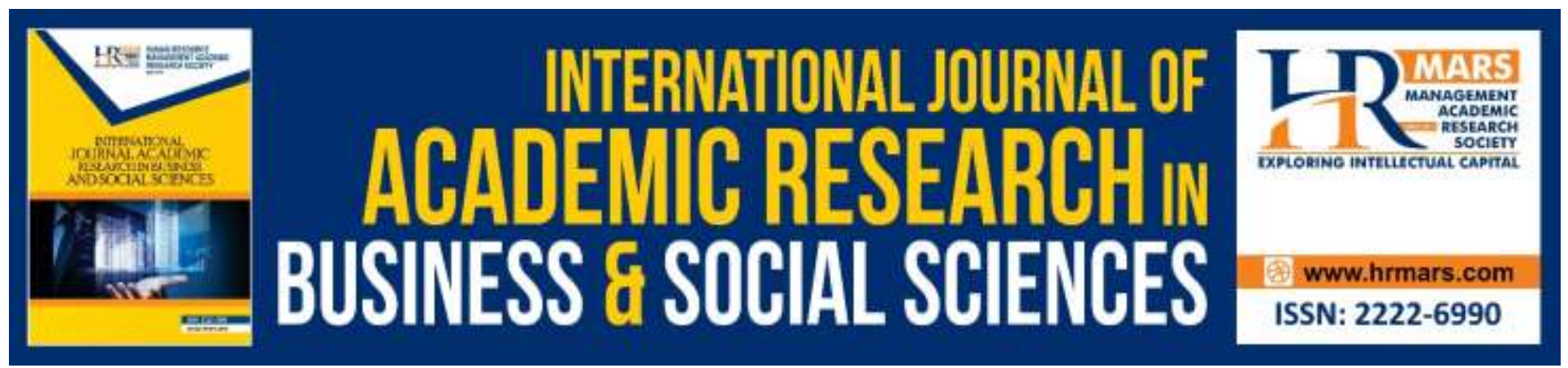

\title{
Fast Food Consumption Behavior among Young Parents: A Qualitative Study with Special Reference to Selected Franchised Fast Food Restaurants Within the Colombo City in Sri Lanka.
}

J. G. K. C Jayawickrama, S. Selvam, T. M Dunumala, Y. A. M. S Samaratunga, H. W. M. C Weligodapola, R. M. N. M. Rathnayake

To Link this Article: http://dx.doi.org/10.6007/IJARBSS/v10-i4/7202 DOI:10.6007/IJARBSS/v10-i4/7202

Received: 08 February 2020, Revised: 04 March 2020, Accepted: 21 March 2020

Published Online: 19 April 2020

In-Text Citation: (Jayawickrama et al., 2020)

To Cite this Article: Jayawickrama, J. G. K., Selvam, S., Dunumala, T., Samaratunga, Y. A. M., Weligodapola, H. W. M., \& Rathnayake, R. M. N. M. (2020). Fast Food Consumption Behavior among Young Parents: A Qualitative Study with Special Reference to Selected Franchised Fast Food Restaurants Within the Colombo City in Sri Lanka. International Journal of Academic Research in Business and Social Sciences, 10(4), 649-661.

\section{Copyright: (c) 2020 The Author(s)}

Published by Human Resource Management Academic Research Society (www.hrmars.com)

This article is published under the Creative Commons Attribution (CC BY 4.0) license. Anyone may reproduce, distribute, translate and create derivative works of this article (for both commercial and non-commercial purposes), subject to full attribution to the original publication and authors. The full terms of this license may be seen at: http://creativecommons.org/licences/by/4.0/legalcode

Vol. 10, No. 4, 2020, Pg. 649 - 661

Full Terms \& Conditions of access and use can be found at http://hrmars.com/index.php/pages/detail/publication-ethics 


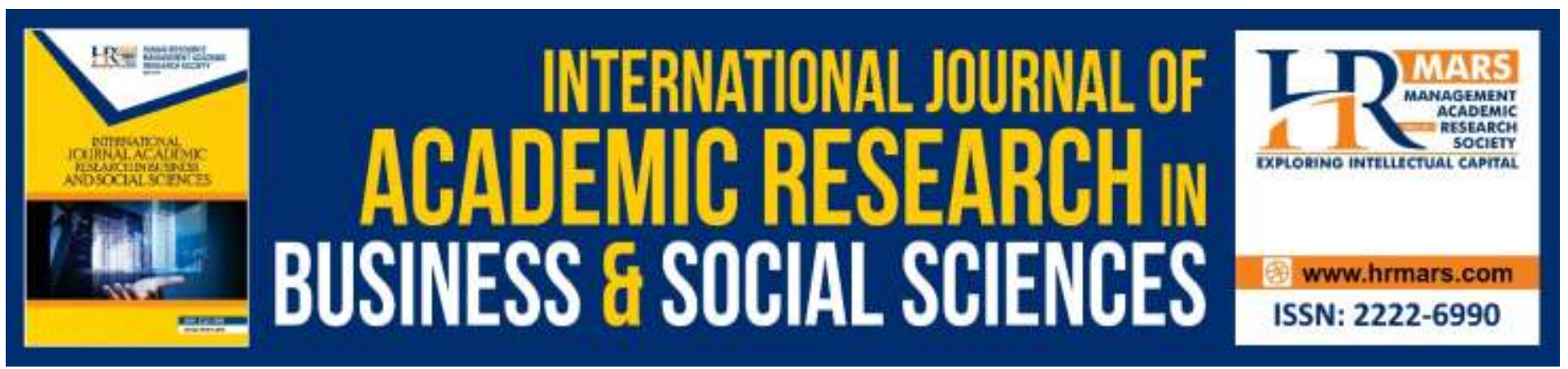

\section{Fast Food Consumption Behavior among Young Parents: A Qualitative Study with Special Reference to Selected Franchised Fast Food Restaurants Within the Colombo City in Sri Lanka.}

J. G. K. C Jayawickrama1 ${ }^{1}$, S. Selvam², T. M Dunumala ${ }^{3}$, Y. A. M. S Samaratunga $^{4}$, H. W. M. C Weligodapola ${ }^{5}$, R. M. N. M. Rathnayake ${ }^{6}$ ${ }^{1}$ Undergraduate, SLIITBusiness school, SLIIT, Malabe, Sri Lanka, ${ }^{2}$ Undergraduate, SLIIT, Business school, SLIIT, Malabe, Sri Lanka, ${ }^{3}$ Undergraduate, SLIIT, Business school, SLIIT, Malabe, Sri Lanka

${ }^{4}$ Undergraduate, SLIIT, Business school, SLIIT, Malabe, Sri Lanka, ${ }^{5}$ Senior Lecturer, SLIIT, Business school, SLIIT, Malabe, Sri Lanka, ${ }^{6}$ Lecturer, SLIIT Business school, SLIIT, Malabe, Sri Lanka

Email: keshalajayawickrama@gmail.com, selvamsusmitha03@gmail.com, michelledunumala@gmail.com,mayumishehani11@gmail.com,mano.w@sliit.lk, nilmini.r@sliit.lk.

\section{Abstract}

Fast food consumption has been a growing trend mainly in the western world for nearly three decades. Families with young children are a major consumer segment of this industry. The purpose of this research was to improve our understanding of family behavior in restaurants by utilizing an ethnographic study of young parents (having children of 2 to 12 years of age) dining in selected fast food restaurants. The problem area being reflected through this research paper is to identify the constructs influencing the role of young parents in this rapidly growing fast-food industry. This research adopted a direct unobtrusive observation to gather qualitative data of a sample of 50 young parents, sampled with the use of purposive sampling technique and thematic analysis to analyze the observations. Food ordering process took around 4-5 min and technoference was not visible to be significant. Minimum personal technology usage by children and moderate usage of restaurant play areas were identified. The kids' meal were recognized to be not imposing a great influence towards restaurant selection. An emergent model is introduced with four independent variables, family decision making, family interactions, technology usage and the usage of play area and the restaurant provided toy affecting the young parents' dining behavior.

Keywords: Dining Behavior, Family Time, Fast-Food, Ordering and Dining Preferences, Young Parents. 


\section{Introduction}

Sri Lanka being a developing country, is experiencing rapid globalization opening doors for many international companies to enter the Sri Lankan market. One such improved industry in Sri Lanka is "Franchised Fast Food". The international fast food chain has spread across the island and influenced lifestyles. A research done by (Patabandige \& Yapa, 2016) says that social and psychological changes such as busy lifestyle has led people to grow fond of fast food as fast-food is the fastest growing type of food which is quick, convenient and readily available (Mat, Zulqernain, \& Zaid, 2016). The developing nation has also impacted the traditional food culture in Sri Lanka. Due to factors like; growing contribution of women workforce, increasing household income, declining number of family, urbanization, development in tourism industry, growing level of education, promotion activities by fast food restaurants, and marketing system (Saraniya \& Thevaranjan, 2015). For that reasons lifestyle of young parents with children aged 2-12 (Kellershohn, Walley, West, \& Vriesekoop, 2018) has changed and this has influenced heavily in choosing to dine out at a franchised fast food restaurant. The dining out behavior is considered as the food eaten away from home (Paddock, Warde, \& Whillans, 2017).

The young parents segment is an important segment as the parents are the main source of information which influences children's behavior in future (Webley \& Nyhus, 2006). A research also explains that child eating behavior is strongly influenced by the family eating behavior (Scaglioni, Salvioni, \& Galimberti, 2008). However, in the context of Sri Lanka, there are no research done in the customer profile of young parents, therefore this study will be based on the dining behavior of young parents that is affected by a few constructs such as family interaction, technological usage, time take to place and receive the order and the usage of play areas/toys. The study will provide significance to other industries in Sri Lanka such as medical, supermarket chains and other local fast food restaurants to consider on the young parents customer segment by understanding their dining out behavior.

\section{Statement of the Problem}

While going over similar previous literature conducted on the subject area of young parents and their dining behavior from all over the world an empirical gap was noticed to be existing in the Sri Lankan context. A comparatively fewer number of studies have been conducted on the segment of young parents in Sri Lanka who are identified as an important segment of customers to the franchised fast food industry as they always tend to visit along with their families comprised of younger children. According to a study, children between the ages of 2- 17 have been found out to be contributing to about $24 \%$ of the industries total marketing expenditure (Ohri-Vachaspati et al., 2015). The collaboration of young parents towards the franchised fast food industry is deemed important as they participate in purchase activities along with their children who will gradually develop the habit of consuming fast food ensuring a future customer base for the franchises. The study would generate a theoretical significance to the context of young parents and their dining behavior with its completion.

\section{Research Objectives}

1. To identify the constructs which affect the dining out behavior of young parents at franchised fast food restaurants.

2. To create an emergent theoretical model with the identified constructs. 
INTERNATIONAL JOURNAL OF ACADEMIC RESEARCH IN BUSINESS AND SOCIAL SCIENCES Vol. 10, No. 4, April, 2020, E-ISSN: 2222-6990 @ 2020 HRMARS

\section{Literature Review}

With a growing business-wise supply of spaces for family outings DeVault (2000), many businesses have expanded their target audience, inviting in more families. The food services industry adopted accordingly by adjusting their food, ambiance and practicalities/ children's needs (Karsten, Kamphuis, \& Remeijnse, 2015). In this industry, franchised fast food restaurants, "food service outlets quickly serving inexpensive foods with minimal preparation and table services" (Fleischhacker, Evenson, Rodriguez, \& Ammerman, 2011) have managed to attract this market segment successfully.

"Family" can be considered the primary decision making unit of the society even though its role have been deflected slightly with societal advancements. . It was found that children who are older than the age of 5 years show more tendency to be involved in the decision making process when the families eat out, similar to the extent which their parents would be. The children will be involved in recognizing the problem, providing information, deciding the restaurant but will not be included in making the final decision and deciding how much will be spent (Nelson, 1979). According to Choudhury (2017), when families eat out, the children tend to play different roles in the process of decision making and features like, taste, popularity amongst children, brand name, availability of entertainment were identified determining factors. Several studies on family decision making states that even though parents are well educated of the negative effects of fast food and have a good nutritional knowledge, they would sometimes have to purchase fast food based on pressure from the family (Janssen, Davies, Richardson, \& Stevenson, 2018).

In the modern world, spending enough leisure time with the children is identified one of the key attributes of good parenting. According to Karsten et al. (2015) requirement for family leisure time could be considered one reason for families to dine out away from home. Family time is identified as a source of memories which are positive, highly valued, involves togetherness and most of the time are unscheduled (Daly, 2001). A study conducted on parent child training interventions elaborates that the children develop their food related choices with $32 \%$ influence from the parents, $7 \%$ influence from the family in general and only $15 \%$ from the marketing efforts like advertising and packaging (Webster-Stratton \& Hammond, 1997).

"Technoference", which is the technology-based interference in parent-child interactions is also identified a growing concern in family dining experiences where low real time interactions happen due to technological interferences (Kellershohn et al., 2018). While some studies point out how obsessed the children are with their mobile devices Davis, Ferdous, and Vetere (2017) a few other studies state that the parents sometimes offer mobile devices to the children if they started misbehaving while the parent is busy using technology (Radesky et al., 2014).

It was recognized that fast food is intensely marketed targeting children and youth who contribute to about $24 \%$ of the industries total marketing expenditure of this industry (Ohri-Vachaspati et al., 2015). According to the Federal Trade Commission in USA, in 2006 majority of the expenditure spent by franchised fast food restaurants in child directed marketing efforts were spent on toy premiums and other CPTIs (Leibowitz, Rosch, Ramirez, Brill, \& Ohlhausen, 2012).

Even though many past studies have addressed these issues focusing on developed countries, the applicability of the same phenomena might vary in developing countries like Sri Lanka. Thereby the current study aims to study the applicability of the above discussed phenomena to the Sri Lankan young parent customer segment of franchised fast food restaurants. 
INTERNATIONAL JOURNAL OF ACADEMIC RESEARCH IN BUSINESS AND SOCIAL SCIENCES Vol. 10, No. 4, April, 2020, E-ISSN: 2222-6990 @ 2020 HRMARS

\section{Methodology}

The current study follows the grounded theory which allows the development of theory by systematically analyzing grounded data (Noble \& Mitchell, 2016). Enforcing an unobtrusive observational approach, a semi structured observational instrument is used to explore on the constructs which affect the young parents' (who has child/children between the age of 2 to 12 years) dining out behavior. This was conducted on 5 selected franchised fast food restaurants located in Colombo City.

\section{Observational Method}

The researchers pretended to be customers by ordering food at each visit and made sure to find a good seating arrangement to unobtrusively observe the young parents and take down notes (Patton, 2002). The restaurant manager and the staff were not informed of the observation. 50 young parents were observed during the year end school holidays on the weekends, for 10 days at 5 busiest franchised fast food outlets during the weekends. The visits were made during the lunch time from $12 \mathrm{pm}$ to $2 \mathrm{pm}$. The researchers used a semi structured observation sheet to note down the young parents' behavior from the moment each family entered the restaurant till they left. Ordering decisions made, length of time taken to place and receive the order, length of time mobile phones were used during the ordering process and while eating was observed. In addition, whether food was ordered for each family member or shared between the families, the parent child interaction and usage of the play area and the

Restaurant provided toy were observed. Extra field notes were also taken down apart from the structured points on the observational instrument.

The transcribed observational data were analyzed with the use of thematic analysis. Themes were identified by coding the data. With the help of these themes, common patterns in the behaviors of young parents' dining out were identified (Braun \& Clarke, 2012).

\section{Table 1- Observed sample}

\begin{tabular}{|l|l|l|l|}
\hline $\begin{array}{l}\text { Restaurant } \\
\text { Label }\end{array}$ & $\begin{array}{l}\text { Number of } \\
\text { families }\end{array}$ & $\begin{array}{l}\text { Number of } \\
\text { parents observed }\end{array}$ & $\begin{array}{l}\text { Number of } \\
\text { children observed }\end{array}$ \\
\hline A & 9 & 14 & 11 \\
\hline B & 6 & 11 & 9 \\
\hline C & 7 & 12 & 12 \\
\hline D & 11 & 17 & 19 \\
\hline E & 17 & 29 & 24 \\
\hline Total & 50 families & 83 parents & 75 children \\
\hline
\end{tabular}

Source: Authors' compilation

\section{Results and Findings}

After analyzing the observed data, four different themes were identified. They are; the family decision making, family interactions, technology usage and usage of play area \& toys. 
INTERNATIONAL JOURNAL OF ACADEMIC RESEARCH IN BUSINESS AND SOCIAL SCIENCES Vol. 10, No. 4, April, 2020, E-ISSN: 2222-6990 @ 2020 HRMARS

\section{Family Decision Making}

To identify the family decision making, the process was observed under two construct. How the ordering decision is being made and the type of order each family place.

\section{Ordering Decision}

Most of the children did not know what they wanted to order as soon as they have arrived at the franchised fast food restaurant. The ordering decisions were solely made by the mother in $26 \%$ of the families. Both the parents were involved in making the decision of $20 \%$ of the families observed where the children did not get involved with the ordering decision. Only $10 \%$ of the families showed an interaction between both the parents and children in making the ordering decisions. In few instances, either only the father and child or the mother and child made the ordering decision collectively.

\section{Type of Order Placed}

The types of orders recognized from observations were, individual food items for each member of the family, and food items for only certain members of the family, snack/ dessert orders and takeaway orders.

From the total of 50 families observed, an average of $76 \%$ ordered individual food items for each member of the family. $20 \%$ ordered food items for only certain members of the family while $4 \%$ placed snack/ dessert orders. A minimum of at least 2 takeaway orders were seen per each hour of the visits.

Among the families who placed orders for individual meals, an average of $76 \%$ shared their food items with each other while only a $24 \%$ enjoyed their own meal without sharing.

The $4 \%$ of the families who ordered snack/ dessert did not share while the whole $10 \%$ of the families who ordered food items for only for the child/ children shared the food with the other members who did not get any food ordered.

Table 2- Type of order placed

\begin{tabular}{|l|l|l|}
\hline Type of order placed & $\begin{array}{l}\text { Total count and } \\
\text { percentage }\end{array}$ & Sharing of food \\
\hline Individual orders for each member & $\begin{array}{l}38 \text { families } \\
76 \%\end{array}$ & $\begin{array}{l}\text { Yes }=76 \% \\
\text { No }=24 \%\end{array}$ \\
\hline Order only for the child/children & $\begin{array}{l}10 \text { families } \\
20 \%\end{array}$ & $\begin{array}{l}\text { Yes }=100 \% \\
\text { No }=0 \%\end{array}$ \\
\hline Snack/ dessert orders & $\begin{array}{l}2 \text { families } \\
4 \%\end{array}$ & $\begin{array}{l}\text { Yes }=0 \% \\
\text { No }=100 \%\end{array}$ \\
\hline
\end{tabular}

Source: Authors' compilation

\section{Family Interactions}

Through previous literature, the constructs selected to study the family interactions were; sharing of food, and time spent on eating in the selected franchised fast food restaurants. 
INTERNATIONAL JOURNAL OF ACADEMIC RESEARCH IN BUSINESS AND SOCIAL SCIENCES Vol. 10, No. 4, April, 2020, E-ISSN: 2222-6990 @ 2020 HRMARS

\section{Sharing of Food}

It was observed that $82 \%$ of young parents and children shared food among each other. Increasing dining party size and having children below the age of 6 who need to be fed were two factors noticed which increased the behavior of sharing food. Only $18 \%$ were visible to not share any food and those dining parties usually comprised of less members, and children above 8 years of age who are able to eat a meal on their own. Sharing of food among the family members is visible to be a common concept in Sri Lankan context.

\section{Time Spent on Eating}

During the observations $14 \%$ of the young parents spent an average of 10 to 30 minutes dining. The factors which were observed to be influencing the length of dining time were; the size of the meal they consumed as well the size of the dining party. A vast majority of $76 \%$ of the young parents were observed to be spending 30 to 60 minutes to dine and an $8 \%$ spent over an hour as they were also engaged in other interactions with their family such as; feeding the child or children, enjoying their time in the restaurant considering it as a time away from home to enjoy with the family. And a minor $2 \%$ of young parents spent less than 10 minutes in the dining process. This group of families were observed to visit the restaurants with their children to take a quick bite on the move. Apart from the 50 families observed around a total of 15 young parents were seen to be placing takeaway orders during the course of observations.

\section{Technology Usage}

Technology usage was studied in accordance to two aspects. Personal technology usage of parents and that of children. Each of this aspect was observed under three situations; usage of mobile phone while waiting to order, usage of mobile phone while waiting till they receive the order and usage of mobile phone while eating.

\section{Table 3- Personal technology usage}

\begin{tabular}{|l|l|}
\hline Technology Usage & Percentage \\
\hline Personal technology usage by parents & $42 \%$ \\
\hline Personal technology usage by children & $2 \%$ \\
\hline No personal technology usage by either the parents nor children & $56 \%$ \\
\hline
\end{tabular}

Source: Authors' compilation

\section{Usage of mobile phone while waiting to order}

A few young parents were seen to be using their phones while waiting in the queue to place their order. Some of them just had their mobile phone in their hands when joining the queue, where some stayed in the queue looking at the menu boards or the television which was hung close to the cashier. Even when the queue moved faster, a minimum time period of 2 minutes and a maximum time period of 5 minutes were observed for mobile phone usage while waiting on queue.

Women using mobile phones while waiting in the queue was less compared to men. It was observed that $42 \%$ of mothers used the mobile phones for less than or equal to 5 minutes whereas $47 \%$ of mobile phones were used by fathers. 
INTERNATIONAL JOURNAL OF ACADEMIC RESEARCH IN BUSINESS AND SOCIAL SCIENCES

Vol. 10, No. 4, April, 2020, E-ISSN: 2222-6990 @ 2020 HRMARS

Among the total of 50 families observed, only $38 \%$ of young parents were noticed using the mobile phones while waiting to place the order. The vast remaining majority of $62 \%$ were concerned with deciding what to order and were noticed interacting with the family.

\section{Usage of Mobile Phone While Waiting till They Receive the Order}

Usage of mobile phone while waiting till their order was received was comparatively high, when comparing it to the usage of phone while waiting in line to order. It was observed that $56 \%$ used their mobile phones till they receive their order. As per the observation an average time of 3 min $36 \mathrm{~s}$ were observed with the maximum time of 7 minutes and minimum time of 1 min being recorded.

Most of the parents used their mobile phones to create a family interaction. Only $2 \%$ of the young parents were engrossed in their mobile phones while some young parents were noticed to be only using it to make a call or send a text message. "Technoference" (Technology based interference) was not observed to be a significant phenomenon in the Sri Lankan context.

\section{Usage of Mobile Phone While Eating}

Usage of mobile phone while eating was observed to be $44 \%$, which is high compared to the mobile phone usage while waiting and low compared to the usage during the wait time. The parents concentrated mainly on meal sharing, enjoying their meals and feeding their children. Some parents used their mobile phones only for a brief minute to make a call, send a text or to take a picture while $4 \%$ of these parents used it for a maximum time period of 25 minutes.

In $10 \%$ of the 50 observed families, both the parents were using their mobile phones till the child/children finish their meal. Only one child was noticed using the mobile phone for 20mins straight while eating. In majority of the cases, the parents were reluctant in allowing the children use their mobile phones.

\section{Usage of Play Area and Restaurant Provided Toy}

From the 50 families observed children from $20 \%$ of the families visited the play area and the maximum time the children spent in the play areas was observed to be 12 minutes while most of them spending an average time of 8-10 minutes. Less parent-child interaction was observed overall within the play area and the parents of two families even went inside the play area with their children to take pictures.

Only $4 \%$ of the total sample were spotted placing an order for a kid's meal and using a toy provided, even though most franchised fast-food restaurants promoted their kid's meal using famous cartoon characters during the period of observations, most of the children were not highly attracted to them, and even the families which received the free toy with the meal did not show noticeable interaction with it.

\section{Empirical evaluation of time taken to place and receive the order}

In the total of 50 families observed, an average time of 4 min $18 \mathrm{~s}$ was spent on placing the order with the highest duration being recorded as 13 minutes while the majority were placed within 3-4 minutes. Factors like hectic business hours and family involvement in deciding what to order were observed to be manipulating the time taken to place the order. According to observations conducted in Canada, 
INTERNATIONAL JOURNAL OF ACADEMIC RESEARCH IN BUSINESS AND SOCIAL SCIENCES Vol. 10, No. 4, April, 2020, E-ISSN: 2222-6990 @ 2020 HRMARS

three factors were identified to be influencing the length of time taken to place the order. They were; Size of party, customers' age and ordering a child's meal bundle (Kellershohn et al., 2018).

Based on the observations, $80 \%$ of the families comprised of only the members of a usual household, the mother, father and their children. Whereas, the remaining $20 \%$ visited the restaurants as a group of two or more families. The larger the size of the dining party, more interactions, more time being spent in the restaurant, more time taken to place the orders and segregated order placements were observed. The $80 \%$ of the families which comprised of the parents and the children depicted a comparatively lesser time spent in the restaurant, less interactions and comparatively less consumption of time to place the order.

All observed young parents were either from the early thirties or the late thirties but none were observed from the ages over 50 showing comparatively lesser preference towards fast food among older young parents. And the time taken to place the order also did not fluctuate drastically as suggested by the study conducted in Canada.

Most families who interacted with other members to arrive at the order decision spent 4 minutes to place the order and an average of 6 minutes 47s were spent by all 30 families who made a collective order decision. The 20 families who placed orders without interacting with any of the family members was recorded an average of $4 \mathrm{~min} 2 \mathrm{~s}$. The average time spent waiting to receive the order was 8 min $6 \mathrm{~s}$ while the most repeated time observed was 5 minutes. 
INTERNATIONAL JOURNAL OF ACADEMIC RESEARCH IN BUSINESS AND SOCIAL SCIENCES Vol. 10, No. 4, April, 2020, E-ISSN: 2222-6990 @ 2020 HRMARS

\section{Emergent Model}

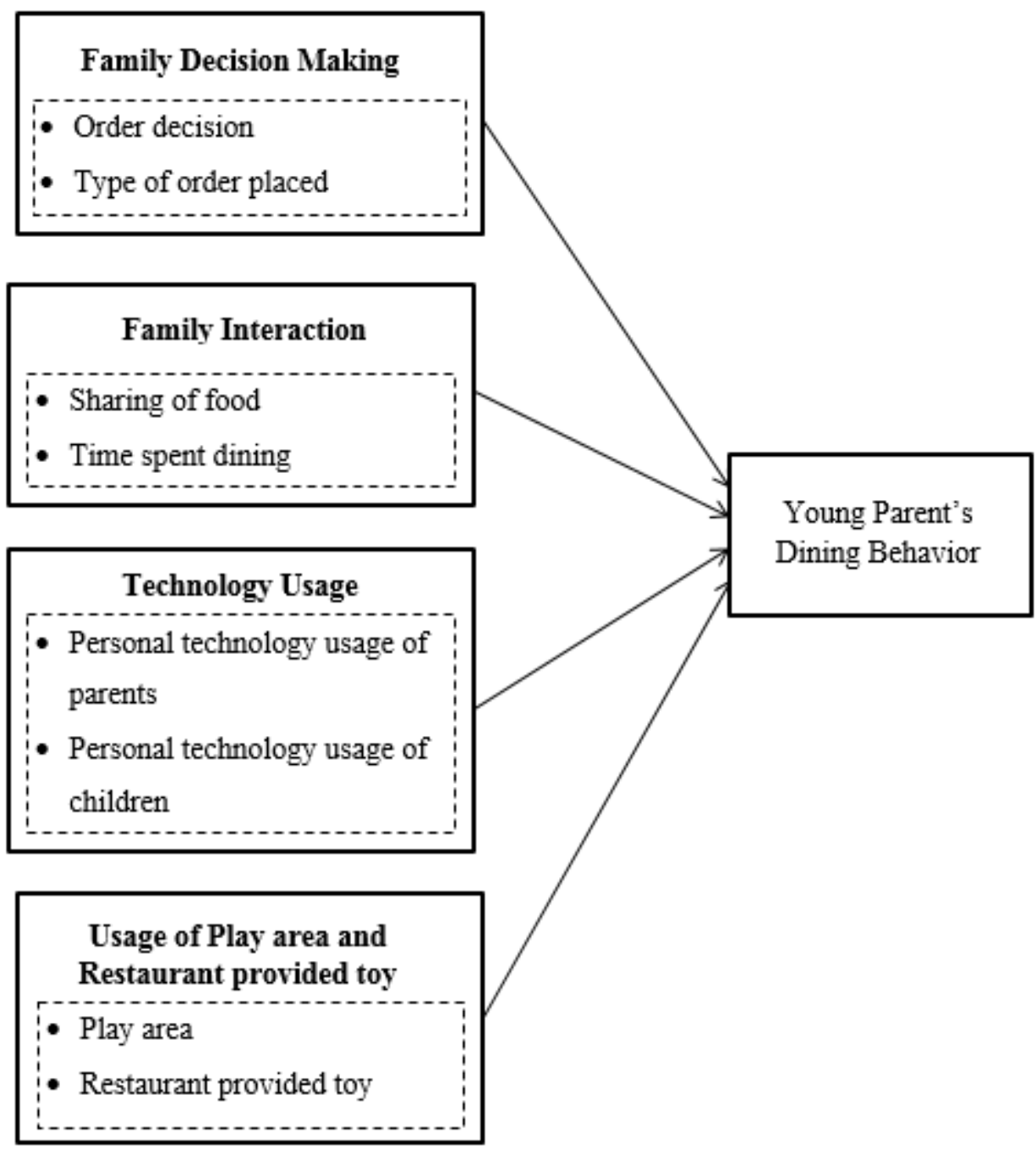

Figure 1- Emergent Model- Authors' representation based on observations

After conducting this ethnographic study, four independent constructs were identified impacting the young parent's dining behavior. Each construct is divided in to accompanying sub constructs which the main constructs were observed to be distinctly composed of.

\section{Conclusion}

The main four constructs identified to be influencing the dining out behavior were the family decision making, family interaction, technology usage and the usage of play area and the restaurant provided toy. The ordering decision is generally made by the parents, this also depends on the child's age. Sharing of food among the family members is a common concept in the Sri Lankan context. But this phenomenon depends on a range of factors such as; the dining party size, child/children's age, and the meals offered by the franchised fast food restaurants. 
INTERNATIONAL JOURNAL OF ACADEMIC RESEARCH IN BUSINESS AND SOCIAL SCIENCES Vol. 10, No. 4, April, 2020, E-ISSN: 2222-6990 @ 2020 HRMARS

An $82 \%$ of the families shared the food items while only $18 \%$ ate alone. Majority of the families spent 30 to 60 minutes to dine at a franchised fast food restaurant while some families would spend more than one hour to dine.

A comparatively minute percentage of technology usage by children was observed making that subconstruct less prominent, but parents showed noticeable personal technology usage patterns also depicting a tendency of personal technology usage to get increased in future. The play area usage was identified moderate but the toys given by the franchised fast-food restaurants were identified not very significant influencing factors in selecting the restaurant. Thus the two sub constructs, the personal technology usage by children and the usage of restaurant provided toy can be considered to be having less prominence when compared to the other sub constructs included in the emergent model. The average time taken to place the order was recorded to be $1 \mathrm{~min} 17 \mathrm{~s}$ and the average wait time to receive the order was 2 min 53 s which are both less than what is observed in the Sri Lankan context. In general young parents and their children were seen to be spending a considerable amount of quality time during their visits to franchised fast food restaurants.

The study provides significance to the franchised fast food industry in the form of managerial implication by exploring the dining out behavior of Sri Lankan young parents and studying the possible impacts which can be generated from several different constructs. The insightful findings of the study will be able to be utilized by the industry in the future to grow its market share by facilitating a favorable atmosphere to attract more, young parent families. The study also holds a theoretical contribution, whereby the findings from the present study would add up to the literature based on the context of young parents and their dining behavior. The suggested emergent model would contribute in the form of a theoretical framework to the successful conduction of future studies on the dining out behavior of young parents.

\section{Limitations and Future Perspectives}

Limitations arose as the study was focused only to the very urban Colombo city of Sri Lanka and the results might vary slightly if different districts were considered. The results from this study might have some extent of subjective bias as interpretation of the observations was done solely by the researchers. To leave out the biasness, future studies can empirically test out the model introduced using qualitative analysis techniques. The study depicting very low impact being generated from the investments made on cross promotional tie ins such as toys by franchised fast food restaurants, also suggests the fast food industry in Sri Lanka to either cut down the investments made on such or to make changes to the product and tie-in offering to attract more children.

\section{References}

Braun, V., \& Clarke, V. (2012). Thematic Analysis (Vol. 2). Washington: American Psychological Association.

Choudhury, P. R. (2017). Eat out: children's role in family decision making. Splint International Journal of Professionals, 4(7), 41-46.

Daly, K. J. (2001). Deconstructing family time: from ideology to lived experience. Journal of marriage and family, 63(2), 283-294.

Davis, H., Ferdous, H. S., \& Vetere, F. (2017). 'Table manners' children's use of mobile technologies in family-friendly restaurants. Paper presented at the Proceedings of the $2017 \mathrm{CHI}$ Conference 
INTERNATIONAL JOURNAL OF ACADEMIC RESEARCH IN BUSINESS AND SOCIAL SCIENCES

Vol. 10, No. 4, April, 2020, E-ISSN: 2222-6990 @ 2020 HRMARS

Extended Abstracts on Human Factors in Computing Systems - CHI EA '17. https://dl.acm.org/doi/abs/10.1145/3027063.3053353

DeVault, M. L. (2000). Producing family time: practices of leisure activity beyond the home. Qualitative Sociology, 23(4), 485-503.

Fleischhacker, S. E., Evenson, K. R., Rodriguez, D. A., \& Ammerman, A. S. (2011). A systematic review of fast food access studies. Obesity reviews, 12(5), 460-471. doi:10.1111/j.1467789X.2010.00715.x

Janssen, H. G., Davies, I. G., Richardson, L. D., \& Stevenson, L. (2018). Determinants of takeaway and fast food consumption: a narrative review. Nutrition research reviews, 31(1), 16-34. doi:10.1017/S0954422417000178

Karsten, L., Kamphuis, A., \& Remeijnse, C. (2015). 'Time-out' with the family: the shaping of family leisure in the new urban consumption spaces of cafes, bars and restaurants. Leisure Studies, 34(2), 166-181. doi:10.1080/02614367.2013.845241

Kellershohn, J., Walley, K., West, B., \& Vriesekoop, F. (2018). Young consumers in fast food restaurants: technology, toys and family time. Young Consumers, 19(1), 105-118. doi:10.1108/yc-08-2017-00731

Leibowitz, J., Rosch, J. T., Ramirez, E., Brill, J., \& Ohlhausen, M. (2012). A review of food marketing to children and adolescents: federal trade commission follow-up report. USA: Federal Trade Commission Retrieved from https://www.ftc.gov/reports/review-food-marketing-childrenadolescents-follow-report

Mat, R. C., Zulqernain, N. S., \& Zaid, N. A. M. (2016). Profiling of malaysian young consumers towards fast food consumptions Journal of Applied Environmental and Biological Sciences 20-27.

Nelson, J. E. (1979). Children as information sources in the family decision to eat out. ACR North American Advances, 6, 419-423. Retrieved from https://www.acrwebsite.org/volumes/9588/volumes/v06/NA-06

Noble, H., \& Mitchell, G. (2016). What is grounded theory? Evidence-based nursing, 0, 1-2.

Ohri-Vachaspati, P., Isgor, Z., Rimkus, L., Powell, L. M., Barker, D. C., \& Chaloupka, F. J. (2015). Childdirected marketing inside and on the exterior of fast food restaurants. American journal of preventive medicine, 48(1), 22-30. doi:10.1016/j.amepre.2014.08.011

Paddock, J., Warde, A., \& Whillans, J. (2017). The changing meaning of eating out in three english cities 1995-2015. Appetite, 119, 5-13. doi:10.1016/j.appet.2017.01.030

Patabandige, G. M. J., \& Yapa, S. T. W. S. (2016). Consumer satisfaction of multinational fast food outlets with the service quality and other influencing factors in the western province of sri lanka. International Research Conference on Management \& Finance 299-314.

Patton, M. Q. (2002). Qualitative research \& evaluation methods: Integrating theory and practice ( $3^{\text {rd }}$ ed ed.): Sage publications.

Radesky, J. S., Kistin, C. J., Zuckerman, B., Nitzberg, K., Gross, J., Kaplan-Sanoff, M., . . Silverstein, M. (2014). Patterns of mobile device use by caregivers and children during meals in fast food restaurants. Pediatrics, 133(4), 843-849. doi:10.1542/peds.2013-3703

Saraniya, D., \& Thevaranjan, D. (2015). Personal factors and fast food consumption in colombo divisional secretariat division Journal Of Business Management Science 2(12), 65-74. 
INTERNATIONAL JOURNAL OF ACADEMIC RESEARCH IN BUSINESS AND SOCIAL SCIENCES

Vol. 10, No. 4, April, 2020, E-ISSN: 2222-6990 @ 2020 HRMARS

Scaglioni, S., Salvioni, M., \& Galimberti, C. (2008). Influence of parental attitudes in the development of children eating behaviour. British Journal of Nutrition, 99 Suppl 1, S22-25. doi:10.1017/S0007114508892471

Webley, P., \& Nyhus, E. K. (2006). Parents' influence on children's future orientation and saving. Journal of Economic Psychology, 27(1), 140-164. doi:10.1016/j.joep.2005.06.016

Webster-Stratton, C., \& Hammond, M. (1997). Treating children with early-onset conduct problems: a comparison of child and parent training interventions. Journal of consulting and clinical psychology, 65(1), 93-109. doi:10.1037//0022-006x.65.1.93 